\title{
Effect of overliming and activated carbon detoxification on inhibitors removal and butanol fermentation of poplar prehydrolysates
}

\author{
Yu Zhang, Changlei Xia, Mingming Lu and Maobing Tu* (1)
}

\begin{abstract}
Background: Biomass prehydrolysates from dilute acid pretreatment contain a considerable amount of fermentable sugars for biofuels production. However, carbonyl degradation compounds present severe toxicity to fermentation microbes. Furans (such as furfural and hydroxymethylfurfural), aliphatic acids (such as acetic acid, formic acid and levulinic acid) and phenolic compounds (such as vanillin and syringaldehyde) have been suggested to be the main inhibitors in biomass prehydrolysates. However, no single compound has been determined as the dominant toxic inhibitor. The effects of various detoxification methods on inhibitors removal have not been fully understood.
\end{abstract}

Results: The effects of overliming and activated carbon (AC) detoxification on the removal of inhibitors and butanol fermentation of the poplar prehydrolysates were investigated. Gas chromatography-mass spectrometry (GC/MS) was used to identify and quantify 46 carbonyl compounds as potential inhibitors. It was observed that overliming and AC treatment alone did not make the prehydrolysates fermentable with Clostridium saccharobutylicum. The sequential overliming and AC resulted in a remarkable fermentability and a high butanol yield at $0.22 \mathrm{~g} \mathrm{~g}^{-1}$ sugar. The inhibitor removal in the prehydrolysates treated by overliming and AC was also examined by GC/MS. Overliming removed $75.6 \%$ of furan derivatives and $68.1 \%$ of aromatic monomers. In comparison, AC $(5.0 \% \mathrm{~W} / \mathrm{V})$ removed $77.9 \%$ of furan derivatives and $98.6 \%$ of aromatic monomers. In addition, overliming removed much more 2,5-furandicarboxyaldehyde, 5-ethylfuran-2-carbaldehyde and 2,5-hexanedione than AC did. On the contrary, AC could remove considerably more phenolic acids than overliming. In the sequential detoxification, both dialdehydes/diketones and phenolic acids were extensively removed. This could be the main reason why the sequential detoxification enabled a remarkable ABE fermentation for the prehydrolysates.

Conclusions: This study indicated that the effect of overliming and AC treatment on inhibitors removal was related to their chemical structures. Overliming removed more dialdehydes and diketones than AC treatment, while AC removed more phenolic acids than overliming. Sequential overliming and $A C$ treatment were required to make the prehydrolysates fermentable with C. saccharobutylicum. The study also suggested different detoxification method was needed for ABE fermentation of the prehydrolysate as compared to ethanol fermentation.

Keywords: Prehydrolysates, Carbonyl inhibitors, Detoxification, Acetone-butanol-ethanol (ABE) fermentation

*Correspondence: tumg@uc.edu

Department of Chemical and Environmental Engineering, University

of Cincinnati, 2901 Woodside Drive, Cincinnati, OH 45221, USA 


\section{Background}

Lignocellulosic biomass has the great potential to be used for producing biofuels sustainably [1]. To break down the biomass recalcitrance, diluted acid is typically used to pretreat biomass and enhance cellulose accessibility for subsequent enzymatic hydrolysis [2, 3]. Hemicellulose can be hydrolyzed to monomeric sugars in the prehydrolysates after dilute acid pretreatment and is available for further biofuels production [4]. However, considerable amount of inhibitors have been generated in dilute acid pretreatment, which hinder microbial fermentation [5-9]. Biomass-derived inhibitors include furfural, hydroxymethylfurfural (HMF), aliphatic acids and phenolic compounds $[10,11]$. Several studies have been concentrated on the identification of potential inhibitors [12, 13]. Chen et al. developed a HPLC method to quantify 32 aliphatic acids, aromatic acids, aldehydes and phenolic compounds in a corn stover hydrolysate [14]. Sharma et al. characterized 40 potential acid inhibitors in biomass prehydrolysates with HPLC-MS/MS [12]. Klinke et al. reported 26 degradation products resulted from alkaline treated wheat straw hydrolysates, including acids, furans and phenols [13]. Although significant efforts have been made to identify the potential inhibitors on microbial fermentation, no single compound has been determined to be the dominant inhibitor [15]. Furfural and HMF content has been suggested to be the important indicator of prehydrolysate toxicity, but they are not the major inhibitors [4, 16]. Aromatic alcohols (catechol and coniferyl alcohol) and aromatic aldehydes (4-hydroxybenzaldehyde and syringaldehyde) were also found to inhibit the growth and fermentation of Escherichia coli LY01 [17, 18 , and their toxicity was directly related to the hydrophobicity [19]. Indeed, aldehydes and ketones are generally considered as major detrimental compounds to the microorganisms. For instance, Ando et al. quantified 12 aromatic degradation compounds in the poplar hydrolysates and also investigated the influences on yeast fermentation [20]. The results indicated that the aldehydes and ketones were more inhibitory than the corresponding acids and alcohols. Therefore, the identification and detoxification of aldehydes and ketones in the prehydrolysates are critically needed in biofuels fermentation.

Several methods have been proposed to alleviate the negative effects of the inhibitors in biomass hydrolysates or prehydrolysates, including overliming [21], anion exchange resin treatment [22], activated carbon (AC) [23, 24], sulfite treatment [25], and treatment with laccase and fungi [25]. Overliming has been suggested to be one of the most effective detoxification methods [26, 27]. Alkaline conditions facilitated the aldol reactions between aldehydes and ketones, and the oxidation of carbonyl compounds could potentially mitigate their toxicity [28-30]. Martin et al. observed that overliming partially reduced the concentration of furfural, HMF and phenolic compounds, resulting in an increased ethanol yield from 0.38 to $0.52 \mathrm{~g} \mathrm{~g}^{-1}$ glucose in the yeast fermentation [31]. Although overliming facilitated the yeast fermentation, acetone-butanol-ethanol $(\mathrm{ABE})$ fermentation was still limited due to the remaining inhibitory compounds and high sensitivity of Clostridium [32].

Compared to the chemical detoxification methods, AC removed inhibitors by physical adsorption [33]. Gong et al. reported that $\mathrm{AC}$ provided a comparable productivity $\left(0.40 \mathrm{~g} \mathrm{~L}^{-1} \mathrm{~h}^{-1}\right)$ in the yeast fermentation of sugarcane bagasse hydrolysates, compared with $\mathrm{pH}$ adjustment and ion-exchange resins [34]. Lu et al. found that AC significantly removed most of the furans and phenolic compounds in the hydrolysates, but the butanol production could only be improved to $59.2 \%$ of the control [32]. Wang et al. achieved a $20 \%$ improvement of xylitol yield after AC detoxification [35]. Villarreal et al. conducted fermentation with the prehydrolysate detoxified by $\mathrm{AC}$; however, the highest productivity only reached $37 \%$ of the reference fermentation [36]. In our preliminary study, it was observed that overliming and $\mathrm{AC}$ treatment alone could not make the prehydrolysates fermentable with Clostridium saccharobutylicum. However, the prehydrolysate treated with a sequential overliming and $\mathrm{AC}$ method was fermentable.

In this study, GC/MS without derivatization was used to analyze the composition changes in the poplar prehydrolysates after overliming and AC detoxification. The $\mathrm{ABE}$ fermentability of the detoxified prehydrolysates was examined using $C$. saccharobutylicum. Liquid-liquid extraction with dichloromethane (DCM) was used to isolate the potential inhibitors from the prehydrolysates. It is hypothesized that overliming and AC treatment not only removed some common inhibitors, but also selectively eliminated some specific inhibitors. It is also hypothesized that $\mathrm{AC}$ is more effective in removing phenolic acids due to their hydrophobicity and overliming is more selective in removing certain dialdehydes and diketones due to the base-catalyzed aldol-condensation reactions. As a result, a combination approach is needed to detoxify the prehydrolysates for ABE fermentation. Fermentability of the detoxified prehydrolysates was also compared between yeast and C. saccharobutylicum. This study is expected to further advance the understanding of the potential inhibitors in the biomass prehydrolysates and the detoxification mechanism by overliming.

\section{Results and discussion}

Effects of overliming and activated carbon on inhibitors removal

The potential inhibitors extracted from the poplar prehydrolysates were determined by GC/MS. The 
corresponding 46 inhibitory compounds (Fig. 1a) from untreated prehydrolysates were identified together with their retention time (RT), mass to charge ratio $(m / z)$, and concentrations (Table 1$)$. The inhibitory compounds can be divided into three groups. The first group (RT: 4-13 min) are furan derivatives (such as furfural, 2,5-furandicarboxyaldehyde, and HMF) and aliphatic derivatives (2,5-hexanedione and 3-hexen-2-one). 2,5-furandicarboxyaldehyde and 2,5-hexanedione, as a dialdehyde and a diketone, were first reported in the biomass prehydrolysates. The second group (RT: 13-24 min) are aromatic monomers (such as vanillin, syringaldehyde, and (4-hydroxy-3,5-dimethoxybenzoyl)-acetaldehyde). The third group (RT: $24-37 \mathrm{~min}$ ) are aromatic dimers (such as 4-hydroxyphenyl 3,4,5-trimethoxybenzoate and syringil) and their concentrations are significantly less than the first and second groups of compounds (1-10\%). Their corresponding chemical structures and fragment patterns are shown in Additional file 1: Figs. S1-S46.

Both overliming and $\mathrm{AC}$ significantly removed the identified compounds, especially for aromatic monomers and dimers (Fig. 1). AC treatment appeared to remove a higher percentage of most compounds than overliming except 2,5-furandicarboxyaldehyde, 5-ethylfuran-2-carbaldehyde and 2,5-hexanedione. The sequential overliming and $\mathrm{AC}$ removed most of the first, second and third group compounds (Fig. 1d). Only the sequential approach enabled a dramatic improvement on ABE fermentation of the poplar prehydrolysates in this study.

Specifically for overliming treatment, furfural content was reduced by $78 \%$, from 3360.9 to $736.8 \mathrm{mg} \mathrm{L}^{-1}$ after overliming treatment (determined by GC/MS, Table 1). HMF content was reduced by $65 \%$, from 625.5 to $216.8 \mathrm{mg} \mathrm{L}^{-1}$ (Table 1). Similarly for AC treatment, furfural content was reduced by $79 \%$ and HMF content was reduced by $74 \%$ (determined by GC/MS). Previously, similar results have been reported on the bagasse hydrolysates detoxification by $\mathrm{Ca}(\mathrm{OH})_{2}$ [26]. Sequential treatment with overliming and 5.0\% AC could further reduce the furfural and HMF content to 378.4 and $11.6 \mathrm{mg} \mathrm{L}^{-1}$, respectively (determined by GC/MS). Although furfural and HMF were not the strong inhibitors, they have been suggested to be important indicators for relative toxicity of prehydrolysates [4].

As for the aromatic monomers, overliming removed vanillin, syringaldehyde and acetosyringone by 65,67 and $53 \%$, respectively. However, $5.0 \%$ AC and the sequential approach completely removed all three compounds. This indicated that $\mathrm{AC}$ was more effective in removing aromatic monomers than overliming. As for the aromatic dimers, overliming reduced gentisein by $29 \%$ (from 5.6 to $4.0 \mathrm{mg} \mathrm{L}^{-1}$ ), 4-hydroxyphenyl 3,4,5-trimethoxybenzoate by $56 \%$ (from 4.8 to $2.1 \mathrm{mg} \mathrm{L}^{-1}$ ), while $5.0 \% \mathrm{AC}$ removed all 12 aromatic dimers completely. This suggested AC was more efficient in removing aromatic dimers due to their higher hydrophobicity.

As summarized in Fig. 2, the potential inhibitors from the untreated prehydrolysates are composed of $77.4 \%$ furans, $21.3 \%$ aromatic monomers, and a minor number of aliphatic derivatives and aromatic dimers. The inhibitory effects of the degradation compounds vary considerably according to their chemical structures [6]. Low concentration $\left(<3 \mathrm{~g} \mathrm{~L}^{-1}\right)$ of furfural and HMF was reported to increase $\mathrm{ABE}$ yield with $C$. beijerinckii BA101 [37]. This stimulatory effect could be resulted from the change of redox balance in C. beijerinckii, because NADPH or NADH was used to reduce furfural to furfural alcohol [38]. Aromatic aldehydes (such as benzaldehyde, 2-hydroxybenzaldehyde and vanillin) has been reported to limit the growth and butanol yield of C. acetobutylicum [39].

The results showed overliming removed $75.6 \%$ of furan derivatives and $68.1 \%$ of aromatic monomers (Fig. 2). Base-catalyzed aldol condensations have been suggested to be the main reactions in removing furan aldehydes previously [21]. The same reaction could occur for 2,5-hexanedione. In comparison, 5.0\% AC removed $77.9 \%$ of furan derivatives and $98.6 \%$ of aromatic monomers. More aromatic monomers and dimers have been removed by $\mathrm{AC}$ than those by overliming. It indicated AC was more effective in removing aromatic compounds from the prehydrolysates. Similar results have been reported before [40], in which $38.7 \%$ of furfural and $57.5 \%$ of total phenolic compounds were reduced by $\mathrm{AC}$ and $45.8 \%$ of furans and $35.8 \%$ of the phenolics were eliminated by overliming. Previously, it has been suggested the AC can selectively remove furans and phenolic compounds other than carboxylic acids due to its strong hydrophobicity [41]. Sequential overliming and 5.0\% AC removed the $90.7 \%$ of furans and $99.5 \%$ of aromatic monomers (Fig. 2). Previously, Ultraviolet-Visible (UV-Vis) spectra have been used to monitor furans in the prehydrolysates [42]. In this study, a major peak at $278 \mathrm{~nm}$ was observed in the untreated and treated prehydrolysates (Additional file 1: Fig. S48). The absorbance at $278 \mathrm{~nm}$ dropped by 12.6 and $77.0 \%$ after overliming and $5.0 \% \mathrm{AC}$ detoxification, respectively. It indicated that absorbance at $278 \mathrm{~nm}$ was not only related to furans, but also associated with phenolic compounds. As a result, integration of overliming and $\mathrm{AC}$ treatment could be more effective to remove both furans and phenolic compounds (aromatic monomers and dimers). Its effectiveness will be assessed in the following $\mathrm{ABE}$ fermentation processes.

As for organic acid removal, without derivatization of the extracted samples, few organic acids were detected by GC/MS in this study. Previously, more than 


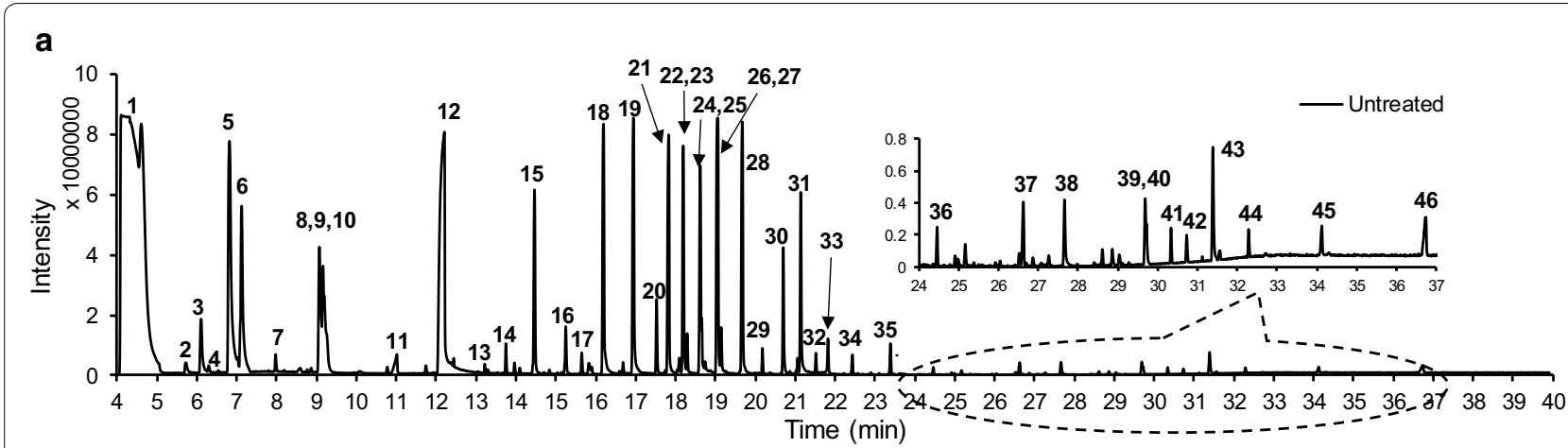

b

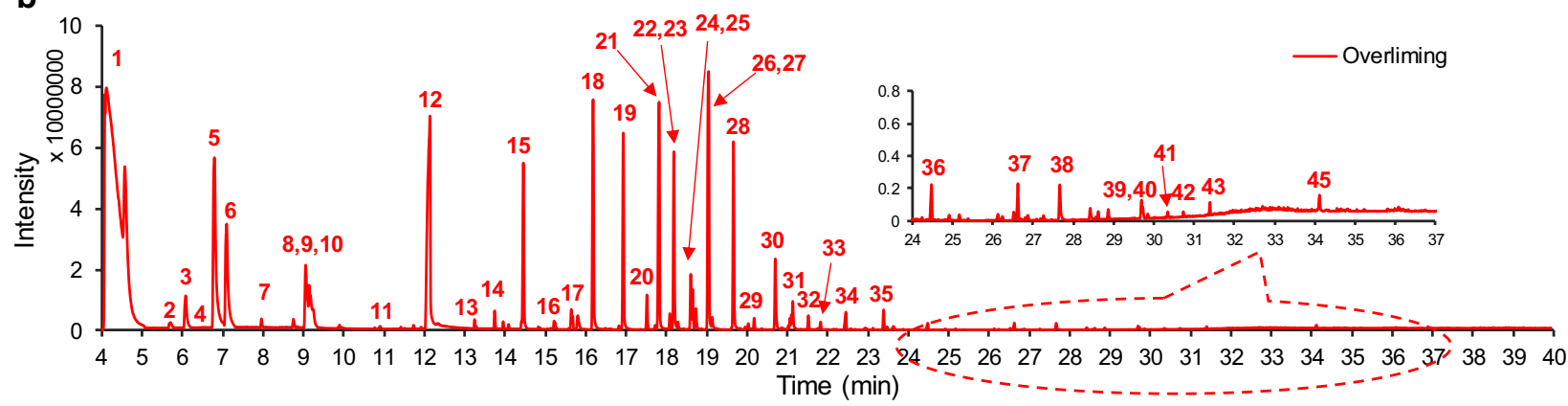

C
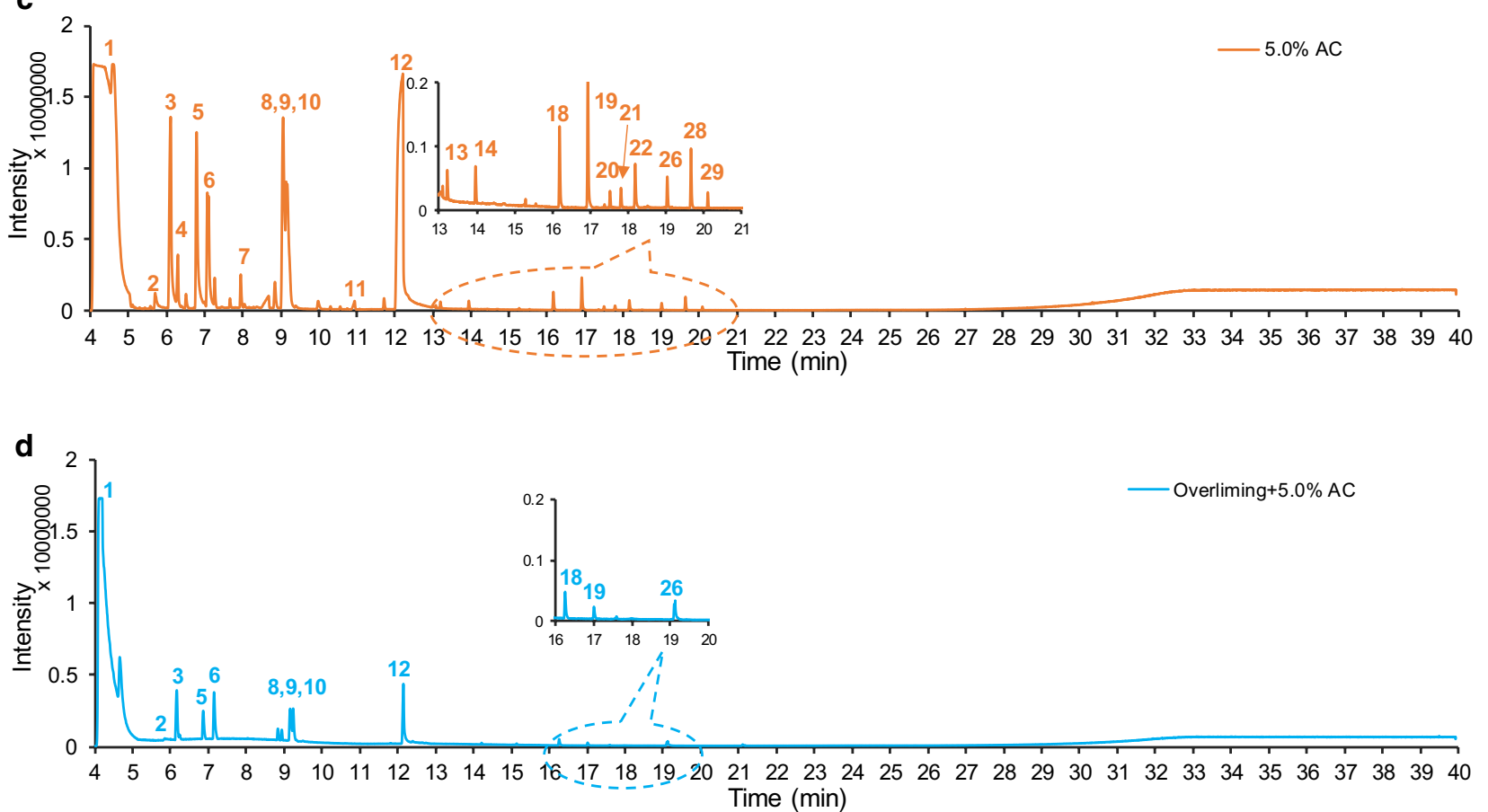

Fig. 1 TIC-GC/MS chromatograms of the prehydrolysates treated with different detoxification methods. a Untreated prehydrolysates, $\mathbf{b}$ overliming; c $5 \% \mathrm{AC}$; and $\mathbf{d}$ sequential overliming and $5 \% \mathrm{AC}$ 
Table 1 Effect of overliming and AC detoxification on inhibitors removal

\begin{tabular}{|c|c|c|c|c|c|c|c|c|}
\hline \multirow[t]{2}{*}{ GC peak } & \multirow[t]{2}{*}{ Compound name } & \multirow{2}{*}{$\begin{array}{l}\mathrm{RT}^{\mathrm{a}} \\
(\mathrm{min})\end{array}$} & \multirow[t]{2}{*}{$m / z$} & \multicolumn{5}{|c|}{ Inhibitor concentration ${ }^{\mathbf{b}}\left(\mathrm{mg} \mathrm{L}^{-1}\right)$} \\
\hline & & & & Untreated & Overliming & $5.0 \% \mathrm{AC}$ & $\begin{array}{l}\text { Overliming }+2.5 \% \\
\text { AC }\end{array}$ & $\begin{array}{l}\text { Overliming }+5.0 \% \\
\text { AC }\end{array}$ \\
\hline & Furan derivatives & & & 4444.3 & 1078.6 & 995.1 & 897.3 & 408.7 \\
\hline $1^{*}$ & Furfural & 4.089 & 96 & 3360.9 & 736.8 & 721.8 & 789.3 & 378.4 \\
\hline $2^{*}$ & 2-Acetylfuran & 5.706 & 110 & 3.3 & 0.9 & 0.9 & 0.9 & 0.8 \\
\hline $5^{*}$ & 5-Methylfurfural & 6.794 & 110 & 156.3 & 27.5 & 16.8 & 25.3 & 1.9 \\
\hline $7^{*}$ & Cyclotene & 7.965 & 112 & 3.8 & 1.0 & 1.7 & 0.7 & NA \\
\hline $8^{* *}$ & 2,5-Furandicarboxyaldehyde & 9.063 & 124 & $148.8^{c}$ & $29.9^{c}$ & $53.6^{c}$ & $11.6^{c}$ & $7.1^{c}$ \\
\hline $9^{* *}$ & 2-Furyl hydroxymethyl ketone & 9.15 & 126 & $88.4^{c}$ & $59.5^{c}$ & $20.3^{c}$ & $34.1^{c}$ & $5.9^{c}$ \\
\hline $10^{*}$ & 5-Ethylfuran-2-carbaldehyde & 9.226 & 124 & 57.3 & 6.2 & 17.6 & 4.4 & 3.1 \\
\hline \multirow[t]{2}{*}{$12^{*}$} & Hydroxymethylfurfural & 12.199 & 126 & 625.5 & 216.8 & 162.4 & 31.0 & 11.6 \\
\hline & Aliphatic derivatives & & & 26.8 & 11.2 & 22.3 & 7.2 & 5.2 \\
\hline $3^{*}$ & 2,5-Hexanedione & 6.094 & 114 & 24.9 & 10.4 & 20.5 & 7.2 & 5.2 \\
\hline \multirow[t]{2}{*}{$4^{* *}$} & 3-Hexen-2-one & 6.286 & 98 & $1.9^{d}$ & $0.8^{\mathrm{d}}$ & $1.9^{d}$ & NA & NA \\
\hline & Aromatic monomers & & & 1198.8 & 383.5 & 17.0 & 48.2 & 4.5 \\
\hline $6^{*}$ & Phenol & 7.109 & 94 & 68.2 & 16.7 & 5.3 & 5.1 & 2.7 \\
\hline $11^{*}$ & Benzoic acid & 11.007 & 122 & 74.9 & 3.8 & 4.7 & 0.4 & NA \\
\hline $13^{*}$ & 3'-Methoxyacetophenone & 13.211 & 150 & 5.6 & 2.1 & NA & 0.8 & NA \\
\hline $14^{*}$ & 3,4,5-Trihydroxybenzaldehyde & 13.74 & 154 & 6.4 & 1.7 & 0.4 & 0.2 & NA \\
\hline $15^{*}$ & Vanillin & 14.458 & 152 & 72.8 & 25.8 & NA & NA & NA \\
\hline $16^{* * *}$ & Homovanillin & 15.263 & 166 & $17.0^{\mathrm{e}}$ & $1.9^{e}$ & NA & NA & NA \\
\hline $17^{*}$ & Acetovanillone & 15.636 & 166 & 10.3 & 9.2 & NA & 0.1 & NA \\
\hline $18^{*}$ & Guaiacylacetone & 16.188 & 180 & 205.5 & 73.5 & 2.0 & 12.8 & 0.9 \\
\hline $19^{* *}$ & $\begin{array}{l}\text { 1-(4-Hydroxy-3-methoxyphenyl) } \\
\text { propane-1,2-dione }\end{array}$ & 16.942 & 194 & $121.0^{\mathrm{e}}$ & $20.3^{e}$ & $2.1^{\mathrm{e}}$ & $4.9^{e}$ & $0.2^{\mathrm{e}}$ \\
\hline $20^{* * *}$ & $\begin{array}{l}\text { 1-(3,4,5-Trihydroxyphenyl)propane- } \\
\text { 1,2-dione }\end{array}$ & 17.522 & 196 & $23.1^{\mathrm{e}}$ & $9.8^{e}$ & $0.2^{e}$ & $1.0^{\mathrm{e}}$ & NA \\
\hline $21^{*}$ & Syringaldehyde & 17.826 & 182 & 110.0 & 36.3 & 0.3 & 1.7 & NA \\
\hline $22^{* * *}$ & Hydroxypropiovanillone & 18.189 & 196 & $83.4^{e}$ & $41.2^{\mathrm{e}}$ & $0.7^{e}$ & $3.5^{e}$ & NA \\
\hline $23^{* *}$ & Homosyringaldehyde & 18.29 & 196 & $9.7^{f}$ & $0.9^{f}$ & NA & $0.1^{f}$ & NA \\
\hline $24^{* *}$ & $\begin{array}{l}\text { 1-Hydroxy-3-(4-hydroxy-3-methoxyphe- } \\
\text { nyl)propan-2-one }\end{array}$ & 18.617 & 196 & $0.7^{e}$ & NA & NA & NA & NA \\
\hline $25^{*}$ & Acetosyringone & 18.653 & 196 & 57.8 & 27.0 & NA & 0.2 & NA \\
\hline $26^{*}$ & Syringylacetone & 19.055 & 210 & 88.5 & 29.7 & 0.3 & 9.5 & 0.7 \\
\hline $27^{*}$ & $\begin{array}{l}\text { 1-(4-Hydroxy-3-methoxyphenyl)-2- } \\
\text { butanone }\end{array}$ & 19.142 & 194 & $11.3^{e}$ & $2.1^{e}$ & NA & NA & NA \\
\hline $28^{* * *}$ & $\begin{array}{l}\text { 1-(4-Hydroxy-3,5-dimethoxyphenyl) } \\
\text { propane-1,2-dione }\end{array}$ & 19.672 & 224 & $104.8^{f}$ & $15.4^{\mathrm{f}}$ & $0.8^{f}$ & $5.7^{f}$ & NA \\
\hline $29^{* * *}$ & $\begin{array}{l}\text { 1-Hydroxy-1-(4-hydroxy-3,5- } \\
\text { dimethoxyphenyl)-2-propanone }\end{array}$ & 20.179 & 226 & $6.7^{f}$ & $4.4^{f}$ & $0.2^{f}$ & $0.3^{f}$ & NA \\
\hline $30^{* * *}$ & $\begin{array}{l}\text { 2-Hydroxy-1-(4-hydroxy-3,5-dimethoxy- } \\
\text { phenyl)propan-1-one }\end{array}$ & 20.701 & 226 & $37.5^{f}$ & $29.2^{\mathrm{f}}$ & NA & $1.5^{\mathrm{f}}$ & NA \\
\hline $31^{* * *}$ & 2-Hydroxy-1-syringyl-ethanone & 21.14 & 226 & $59.7^{f}$ & $23.7^{f}$ & NA & $0.4^{f}$ & NA \\
\hline $32^{* * *}$ & $\begin{array}{l}\text { 1-(3,4,5-Trimethoxyphenyl)-1,2-propan- } \\
\text { edione }\end{array}$ & 21.517 & 238 & $4.9^{f}$ & $2.8^{f}$ & NA & NA & NA \\
\hline $33^{* * *}$ & $\begin{array}{l}\text { (4-Hydroxy-3,5-dimethoxybenzoyl)- } \\
\text { acetaldehyde }\end{array}$ & 21.822 & 224 & $9.5^{f}$ & $0.4^{f}$ & NA & NA & NA \\
\hline \multirow[t]{2}{*}{$35^{* * *}$} & $\begin{array}{l}\text { 1-(4-Hydroxy-3,5-dimethoxyphenyl) } \\
\text { pentane-1,2-dione }\end{array}$ & 23.388 & 252 & $9.5^{f}$ & $5.4^{f}$ & NA & NA & NA \\
\hline & Aromatic dimers & & & 45.9 & 14.2 & NA & NA & NA \\
\hline $34^{* * *}$ & Gentisein & 22.333 & 244 & $5.6^{f}$ & $4.0^{f}$ & NA & NA & NA \\
\hline
\end{tabular}


Table 1 (continued)

\begin{tabular}{|c|c|c|c|c|c|c|c|c|}
\hline \multirow[t]{2}{*}{ GC peak } & \multirow[t]{2}{*}{ Compound name } & \multirow{2}{*}{$\begin{array}{l}\mathrm{RT}^{\mathrm{a}} \\
(\mathrm{min})\end{array}$} & \multirow[t]{2}{*}{$m / z$} & \multicolumn{5}{|c|}{ Inhibitor concentration ${ }^{b}\left(\mathrm{mg} \mathrm{L}^{-1}\right)$} \\
\hline & & & & Untreated & Overliming & $5.0 \% \mathrm{AC}$ & $\begin{array}{l}\text { Overliming }+2.5 \% \\
\text { AC }\end{array}$ & $\begin{array}{l}\text { Overliming }+5.0 \% \\
\text { AC }\end{array}$ \\
\hline $36^{* * *}$ & $\begin{array}{l}\text { 2-(4-Hydroxy-3-methoxyphenyl)-1-(3,5- } \\
\text { dihydroxyphenyl)ethanone }\end{array}$ & 24.465 & 274 & $2.4^{f}$ & $1.9^{f}$ & NA & NA & NA \\
\hline $37^{* * *}$ & $\begin{array}{l}\text { 4-Hydroxyphenyl 3,4,5-trimethoxyben- } \\
\text { zoate }\end{array}$ & 26.633 & 304 & $4.8^{f}$ & $2.1^{f}$ & NA & NA & NA \\
\hline $38^{* * *}$ & $\begin{array}{l}\text { 1,2-Bis(4-Hydroxy-3-methoxyphenyl) } \\
\text { ethanone }\end{array}$ & 27.666 & 288 & $5.3^{f}$ & $2.6^{f}$ & NA & NA & NA \\
\hline $39 * * *$ & $\begin{array}{l}\text { 1-(4-Hydroxy-3,5-dimethoxyphenyl)- } \\
\text { 2-(4-hydroxy-3-methoxyphenyl) } \\
\text { ethanon }\end{array}$ & 29.714 & 318 & $4.5^{f}$ & $1.1^{f}$ & NA & NA & NA \\
\hline $40^{* * *}$ & $\begin{array}{l}\text { 2-(4-Hydroxy-3,5-dimethoxyphenyl)- } \\
\text { 1-(4-hydroxy-3-methoxyphenyl) } \\
\text { ethanone }\end{array}$ & 29.725 & 318 & $2.2^{f}$ & $0.6^{f}$ & NA & NA & NA \\
\hline $41^{* * *}$ & 2-Syringylacetosyringone & 30.345 & 362 & $2.0^{f}$ & $0.2^{f}$ & NA & NA & NA \\
\hline $42^{* * *}$ & Vanillosyringil & 30.748 & 332 & $1.8^{f}$ & $0.2^{f}$ & NA & NA & NA \\
\hline $43^{* * *}$ & $\begin{array}{l}\text { 1,2-bis(4-Hydroxy-3,5-dimethoxyphenyl) } \\
\text { ethanone }\end{array}$ & 31.397 & 348 & $8.4^{f}$ & $0.6^{f}$ & NA & NA & NA \\
\hline $44^{* * *}$ & Syringil & 32.299 & 362 & $1.7^{f}$ & NA & NA & NA & NA \\
\hline $45^{* * *}$ & $\begin{array}{l}\text { 1-(4-Acetyl-3,5-dimethoxyphenyl)- } \\
\text { 2-(4-hydroxy-3,5-dimethoxyphenyl) } \\
\text { ethane-1,2-dione }\end{array}$ & 34.138 & 388 & $2.3^{f}$ & $0.9^{f}$ & NA & NA & NA \\
\hline $46^{* * *}$ & $\begin{array}{l}\text { Phenol, 4,4'-(1,2-ethanediyl)bis[2,6- } \\
\text { dimethoxy-,diacetate }\end{array}$ & 36.744 & 418 & $4.9^{f}$ & NA & NA & NA & NA \\
\hline
\end{tabular}

* The compounds verified with standard

** The compounds compared with reference mass spectrum

*** The compounds derived by the fragments

a RT are shortened for the retention time

b Inhibitor residual was calculated based on the intergradation area of each compound

c The concentration was determined by the calibration of hydroxymethylfurfural

d The concentration was determined by the calibration of 2,5-hexanedione

e The concentration was determined by the calibration of vanillin

$f$ The concentration was determined by the calibration of syringaldehyde

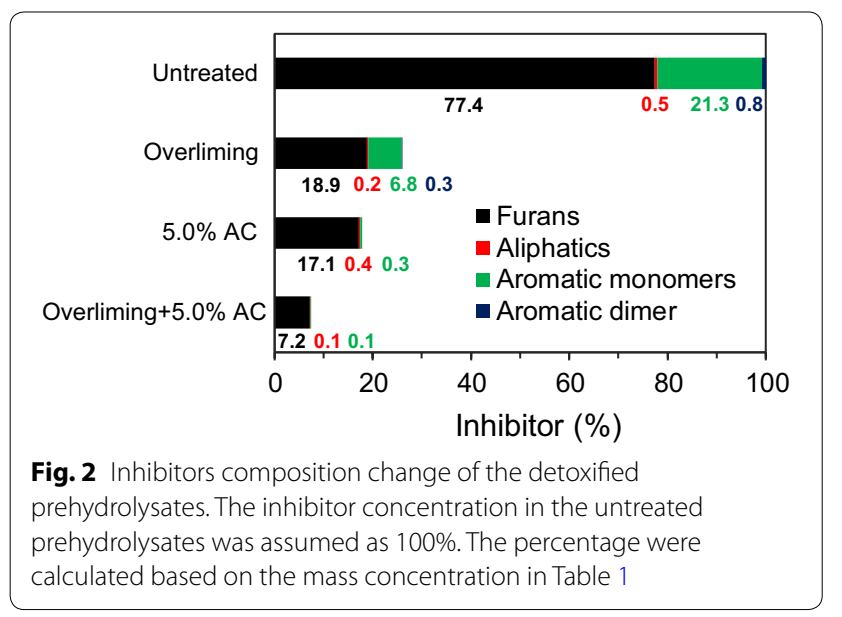

30 aliphatic and phenolic acids have been identified in a poplar hydrolysate after trifluorobis(trimethylsilyl)acetamide and chlorotrimethylsilane derivatization [43]. In this research, HPLC and LC-QTOF were used to determine the short chain aliphatic acids and phenolic acids removal after detoxification (Table 2). It was observed that aliphatic acids were not changed much with overliming and AC treatment, even the sequential overliming and $\mathrm{AC}$ treatment only removed $17 \%$ of formic acid and $10 \%$ levulinic acid. However, the overliming and AC showed significant difference in phenolic acids removal. AC removed considerably more phenolic acids than overliming. The results showed cinnamic acid, dihydroxybenzoic acid, coumaric acid, vanillic acid and ferulic acid could be removed by 100, 100, 100, 85.74 and $10 \%$, respectively, after AC treatment (Table 2). However, they were reduced only by $74.69,13.99,1.13,32.61$ and $60.94 \%$, respectively, after overliming treatment. Consequently, the sequential detoxification removed $96.8 \%$ 
Table 2 Effect of detoxification on organic acid removal

\begin{tabular}{llll}
\hline Compound name & \multicolumn{3}{l}{ Organic acid removal percentage (\%) } \\
\cline { 2 - 3 } & Overliming & $5.0 \%$ AC & Overliming $+5.0 \%$ \\
AC
\end{tabular}

\begin{tabular}{lrrr}
\hline Aliphatic acids & & & \\
Formic acid & 8.0 & 14.0 & 17.0 \\
Acetic acid & 0.0 & 0.0 & 0.0 \\
Levulinic acid & 5.0 & 6.0 & 10.0 \\
Phenolic acids & & & \\
Benzoic acid & 32.2 & 49.5 & 68.2 \\
Cinnamic acid & 74.7 & 100.0 & 100.0 \\
Dihydroxybenzoic acid & 14.0 & 100.0 & 100.0 \\
Coumaric acid & 1.1 & 100.0 & 100.0 \\
Vanillic acid & 32.6 & 85.7 & 93.9 \\
Homovanillic acid & 62.1 & 89.5 & 100.0 \\
Ferulic acid & 60.9 & 100.0 & 100.0 \\
Syringylglycolic acid & 38.8 & 100.0 & 100.0 \\
\hline
\end{tabular}

of the total phenolic acids. The difference in removing the dialdehydes/diketones and phenolic acids by overliming and $\mathrm{AC}$ could be used to explain their synergic effect in detoxification of the prehydrolysates for $\mathrm{ABE}$ fermentation.

It should be noted that both overliming and $\mathrm{AC}$ detoxification would result in sugar loss. The results showed that $7.2 \%$ of sugars were lost in overliming compared to $4.8 \%$ of sugars in $5.0 \% \mathrm{AC}$. The sequential overliming and $5.0 \%$ AC resulted in $8.4 \%$ sugar loss (Table 3 ).

\section{Synergistic effect of overliming and $A C$ on $A B E$} fermentation

$\mathrm{ABE}$ fermentation with $C$. saccharobutylicum was performed with the prehydrolysates detoxified by overliming, 5.0\% AC, and sequential overliming and 5.0\% AC (Table 4). The results showed that both overliming and $5.0 \% \mathrm{AC}$ alone could not make the prehydrolysates fermentable. The sequential overliming and 5.0\% AC resulted in remarkable fermentability and high-butanol yield (0.22 $\mathrm{g} \mathrm{g}^{-1}$ sugar). This agrees well with a recent report on butanol yield by Clostridium beijerinckii CC101 [44]. The final concentration of acetone, butanol and ethanol was 7.1, 13.2 and $1.0 \mathrm{~g} \mathrm{~L}^{-1}$, respectively. The $\mathrm{ABE}$ yield reached $0.35 \mathrm{~g} \mathrm{~g}^{-1}$ sugar, which is similar to the pure glucose fermentation $\left(0.36 \mathrm{~g} \mathrm{~g}^{-1}\right.$ sugar). This indicated that overliming and $\mathrm{AC}$ treatment displayed a synergistic effect on detoxification of the prehydrolysates. Overliming and AC detoxified some common inhibitors such as furan derivatives and phenolic aldehydes and ketones, but also selectively removed some specific inhibitors. Table 1 showed overliming removed much more 2,5-furandicarboxyaldehyde, 5-ethylfuran2-carbaldehyde and 2,5-hexanedione than AC did. For

Table 3 Effect of detoxification on sugar loss and total inhibitor concentrations in the prehydrolysates

\begin{tabular}{|c|c|c|c|c|c|c|}
\hline \multirow[t]{2}{*}{ Treatment } & \multicolumn{5}{|c|}{ Sugar concentration $\left(\mathrm{g} \mathrm{L}^{-1}\right)$} & \multirow{2}{*}{$\begin{array}{l}\text { Total inhibitor } \\
\text { concentration ( } 9 \\
\left.\mathrm{~L}^{-1}\right)\end{array}$} \\
\hline & Glucose & Xylose & Galactose & Arabinose & Mannose & \\
\hline Untreated & $67.85 \pm 1.67$ & $8.93 \pm 0.13$ & $1.04 \pm 0.10$ & $0.64 \pm 0.08$ & $1.94 \pm 0.10$ & 5.68 \\
\hline Overliming & $62.98 \pm 0.31$ & $8.00 \pm 0.23$ & $0.98 \pm 0.11$ & $0.56 \pm 0.11$ & $2.12 \pm 0.12$ & 1.47 \\
\hline $5.0 \% \mathrm{AC}$ & $64.85 \pm 0.38$ & $8.26 \pm 0.03$ & $0.93 \pm 0.05$ & $0.61 \pm 0.05$ & $1.89 \pm 0.13$ & 1.00 \\
\hline Overliming + 5.0\% AC & $62.51 \pm 0.28$ & $7.84 \pm 0.33$ & $0.93 \pm 0.19$ & $0.51 \pm 0.05$ & $1.89 \pm 0.08$ & 0.41 \\
\hline
\end{tabular}

Table 4 Effect of detoxification methods on products yield in ABE fermentation

\begin{tabular}{|c|c|c|c|c|c|c|}
\hline Sample & $\begin{array}{l}\text { Total sugar } \\
\text { after fermentation } \\
\left(\mathrm{g} \mathrm{L}^{-1}\right)\end{array}$ & $C_{\text {acids }}\left(\mathrm{g} \mathrm{L}^{-1}\right)$ & $C_{\text {butanol }}\left(\mathrm{g} \mathrm{L}^{-1}\right)$ & $Y_{\text {butanol }}\left(\mathrm{g} \mathrm{g}^{-1}\right.$ sugar $)$ & $C_{\mathrm{ABE}}\left(\mathrm{g} \mathrm{L}^{-1}\right)$ & $Y_{\mathrm{ABE}}\left(\mathrm{g} \mathrm{g}^{-1}\right.$ sugar $)$ \\
\hline Glucose control & $10.28 \pm 1.10$ & $0.68 \pm 0.08$ & $11.18 \pm 0.03$ & $0.25 \pm 0.01$ & $15.94 \pm 0.16$ & $0.36 \pm 0.02$ \\
\hline Untreated & $67.19 \pm 0.81$ & $6.18 \pm 0.21$ & $0.00 \pm 0.00$ & $0.00 \pm 0.00$ & $0.00 \pm 0.00$ & $0.00 \pm 0.00$ \\
\hline Overliming & $62.01 \pm 1.75$ & $6.05 \pm 0.19$ & $0.00 \pm 0.00$ & $0.00 \pm 0.00$ & $0.00 \pm 0.00$ & $0.00 \pm 0.00$ \\
\hline $5.0 \% \mathrm{AC}$ & $63.70 \pm 1.06$ & $6.22 \pm 0.17$ & $0.00 \pm 0.00$ & $0.00 \pm 0.00$ & $0.00 \pm 0.00$ & $0.00 \pm 0.00$ \\
\hline Overliming $+5.0 \% \mathrm{AC}$ & $5.89 \pm 0.25$ & $3.93 \pm 0.29$ & $13.36 \pm 0.35$ & $0.22 \pm 0.02$ & $21.26 \pm 0.47$ & $0.35 \pm 0.09$ \\
\hline
\end{tabular}

$C_{\text {acids }}$, represents the final concentration of the acetic acid and butyric acid by $96 \mathrm{~h} ; C_{\text {butanol, }}$, represents the butanol production by $96 \mathrm{~h} ; Y_{\text {butanol, }}$ represents the butanol yield at $96 \mathrm{~h}$ based on the total sugar consumption; $C_{\mathrm{ABE}}$, represents $\mathrm{ABE}$ production by $96 \mathrm{~h} ; Y_{\mathrm{ABE}}$, represents the $\mathrm{ABE}$ yield at $96 \mathrm{~h}$ based on the total sugar consumption

a Original sugar concentrations of fermentation were diluted to $90 \%$ of the prehydrolysates due to the inoculum of Clostridium. The initial concentration of glucose control was $54.86 \mathrm{~g} \mathrm{~L}^{-1}$ 
example, 2,5-furandicarboxyaldehyde was reduced from 148.8 to $29.9 \mathrm{mg} \mathrm{L}^{-1}$ by overliming and only to $53.6 \mathrm{mg}$ $\mathrm{L}^{-1}$ by AC. 2,5-furandicarboxyaldehyde and 2,5-hexanedione are a dialdehyde and a diketone. On the contrary, $\mathrm{AC}$ appeared to be much more effective in removing phenolic acids (Table 2). Coumaric acid, vanillic acid and ferulic acid have been reported to inhibit butanol fermentation by Clostridium beijerinckii [45]. In the sequential detoxification, both dialdehyde/diketone and phenolic acids were significantly removed (Tables 1,2 ). This could be the reason why sequential detoxification enabled a remarkable $\mathrm{ABE}$ fermentation for the prehydrolysates. It should be noted that not much aliphatic acids (formic, acetic and levulinic acids) were removed in the sequential detoxification (Table 2).

Previous studies indicated that furans and phenolics were reduced considerably by overliming [4], while formic acid, acetic acid and levulinic acid remained unchanged. Although acetic acid can be consumed by $C$. saccharobutylicum, formic acid and levulinic acid could be toxic to Clostridium. A significant amount of acetic acid $\left(\sim 8.6 \mathrm{~g} \mathrm{~L}^{-1}\right)$ was presented in the detoxified prehydrolysates, most of which was consumed and converted to acetone $\left(7.0 \mathrm{~g} \mathrm{~L}^{-1}\right)$ after $96 \mathrm{~h}$.

\section{Effect of activated carbon dosage in sequential detoxification on $A B E$ fermentation}

$A C$ detoxification efficiency is dependent on how much $A C$ used in the process [23, 46, 47]. In the sequential detoxification process, the prehydrolysates after overliming were further treated with 1.0, 2.5, 5.0 and 10.0\% $(w / v)$ of AC. The results showed that no ABE was produced with the prehydrolysate treated with sequential overliming and $1.0 \% \mathrm{AC}$ (Fig. 3). Approximately $5.6 \mathrm{~g}$ $\mathrm{L}^{-1}$ of butanol and $8.9 \mathrm{~g} \mathrm{~L}^{-1}$ of $\mathrm{ABE}$ were produced with the prehydrolysate treated with sequential overliming and $2.5 \% \mathrm{AC}$. The final acetone and ethanol concentration was 2.8 and $0.4 \mathrm{~g} \mathrm{~L}^{-1}$, respectively. A considerable amount of glucose $\left(28 \mathrm{~g} \mathrm{~L}^{-1}\right)$ remained after $96 \mathrm{~h}$ fermentation. It indicated the prehydrolysate was partially detoxified under this condition. Butanol production reached $13.2 \mathrm{~g} \mathrm{~L}^{-1}$ with the prehydrolysate treated with
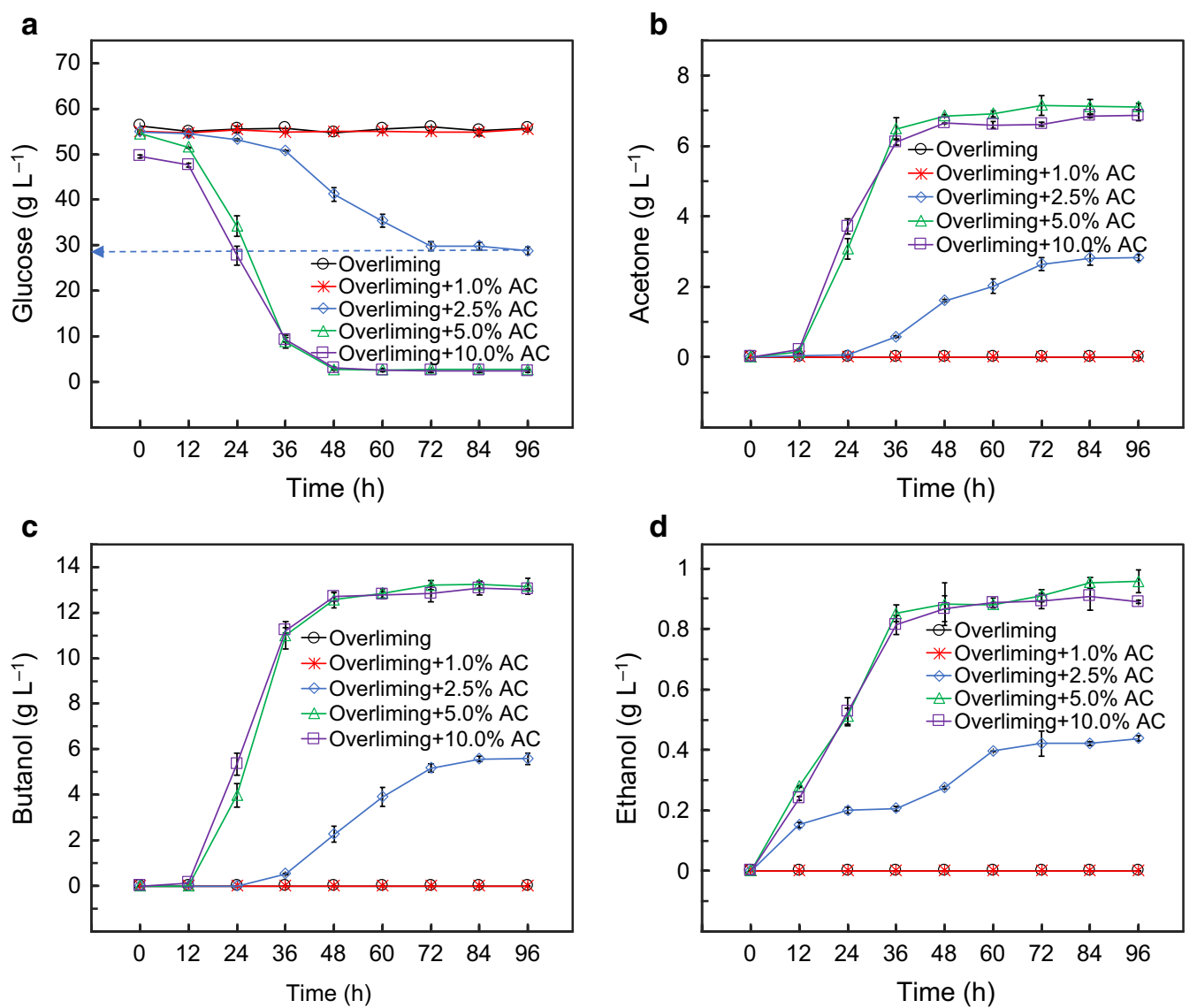

Fig. 3 Effect of sequential detoxification on ABE fermentation of the propolar prehydrolysate. a glucose consumption, $\mathbf{b}$ acetone production, $\mathbf{c}$ ethanol production, and $\mathbf{d}$ butanol production 
sequential overliming and 5.0\% $\mathrm{AC}$. The $\mathrm{ABE}$ production was $21.3 \mathrm{~g} \mathrm{~L}^{-1}$, which were similar to the prehydrolysate treated with sequential overliming and $10.0 \% \mathrm{AC}$. It should be noted that sequential overliming and $10.0 \% \mathrm{AC}$ detoxification resulted in more sugar loss than sequential overliming and 5.0\% AC detoxification. Similar observation of dosage dependence has been reported on the formic acid removal by AC [23], in which $1.0 \%$ AC removed 47.3\% furfural and 5.0\% AC removed $75.5 \%$ of furfural in a hardwood prehydrolysate.

\section{Effect of overliming on yeast fermentation}

To examine the different tolerance between yeast and C. saccharobutylicum, the overliming treated prehydrolysates was fermented with yeast as well (Table 5) [48-50]. The results showed that the overliming detoxified prehydrolysates exhibited fermentability comparable to the glucose control. Specifically, the ethanol yield reached $0.40 \mathrm{~g} \mathrm{~g}^{-1}$ sugar within $12 \mathrm{~h}$. Similar results have been reported by examining the effects of carbonyl inhibitors on the ethanol fermentation [8, 30, 51, 52]. Martiniz et al. obtained an ethanol yield of $0.45 \mathrm{~g} \mathrm{~g}^{-1}$ sugar with Escherichia coli after overliming detoxification [26]. As mentioned above, the overliming treated prehydrolysate was not fermentable with $C$. saccharobutylicum. This indicated that $C$. saccharobutylicum is more sensitive to the prehydrolysate inhibitors and a different detoxification approach is required for $\mathrm{ABE}$ fermentation with $C$. saccharobutylicum.

\section{Effect of reactivated AC on detoxification}

Surface area loss was observed for the spent AC after the detoxification treatment (Fig. 4). The Brunauer-EmmettTeller (BET) surface area of spent AC was $427.1 \mathrm{~m}^{2} \mathrm{~g}^{-1}$, which presented a $17.4 \%$ decrease compared with the value of the original $\mathrm{AC}\left(517.3 \mathrm{~m}^{2} \mathrm{~g}^{-1}\right)$. Additionally, the surface area of micropores (pore size $<2 \mathrm{~nm}$ ) decreased from 244.6 to $173.6 \mathrm{~m}^{2} \mathrm{~g}^{-1}$, which was considered to be the key contribution of molecular adsorption. After thermal reactivation, the surface area could be improved to 98.7\% $\left(510.7 \mathrm{~m}^{2} \mathrm{~g}^{-1}\right)$ of the original AC. The well recovered capability was achieved because the adsorbates (inhibitors) were volatized or thermal decomposed into gases and carbon during the thermal treatments.

To examine whether the $\mathrm{AC}$ can be recycled in the sequential detoxification, the reactivated $A C$ was used in a prehydrolysate detoxification for $\mathrm{ABE}$ fermentation. The results showed that the sugar loss in sequential

Table 5 Effect of overliming on the initial sugar concentrations and yeast fermentations

\begin{tabular}{|c|c|c|c|c|c|c|c|c|}
\hline \multirow[t]{2}{*}{ Sample } & \multicolumn{5}{|c|}{ Initial sugar concentration $\left(\mathrm{g} \mathrm{L}^{-1}\right)$} & \multirow{2}{*}{$\begin{array}{l}\text { Total sugar } \\
\text { consumption } \\
\left(\mathrm{g} \mathrm{L}^{-1}\right)\end{array}$} & \multirow[t]{2}{*}{$C_{\text {ethanol }}^{b}\left(g^{-1}\right)$} & \multirow[t]{2}{*}{$Y_{\text {ethanol }}^{c}\left(\mathrm{~g} \mathrm{~g}^{-1}\right.$ sugar $)$} \\
\hline & Glucose & Xylose & Galactose & Arabinose & Mannose & & & \\
\hline Glucose control & $20.11 \pm 0.36$ & $0.00 \pm 0.00$ & $0.00 \pm 0.00$ & $0.00 \pm 0.00$ & $0.00 \pm 0.00$ & $20.11 \pm 0.36$ & $8.32 \pm 0.20$ & $0.41 \pm 0.07$ \\
\hline Untreated & $19.94 \pm 0.24$ & $8.94 \pm 0.17$ & $1.02 \pm 0.04$ & $0.68 \pm 0.01$ & $2.02 \pm 0.10$ & $1.89 \pm 0.13$ & $0.00 \pm 0.00$ & $0.00 \pm 0.00$ \\
\hline Overliming & $18.76 \pm 0.19$ & $8.25 \pm 0.59$ & $0.87 \pm 0.02$ & $0.67 \pm 0.00$ & $2.24 \pm 0.20$ & $24.59 \pm 0.16$ & $9.82 \pm 0.40$ & $0.40 \pm 0.01$ \\
\hline
\end{tabular}

a Total sugar consumption was calculated by the sum of the reduction of five sugars

${ }^{b} C_{\text {ethanol }}$ represents the ethanol production by $48 \mathrm{~h}$

c $Y_{\text {ethanol }}$ represents the ethanol yield at $48 \mathrm{~h}$ based on the total sugar consumption

a

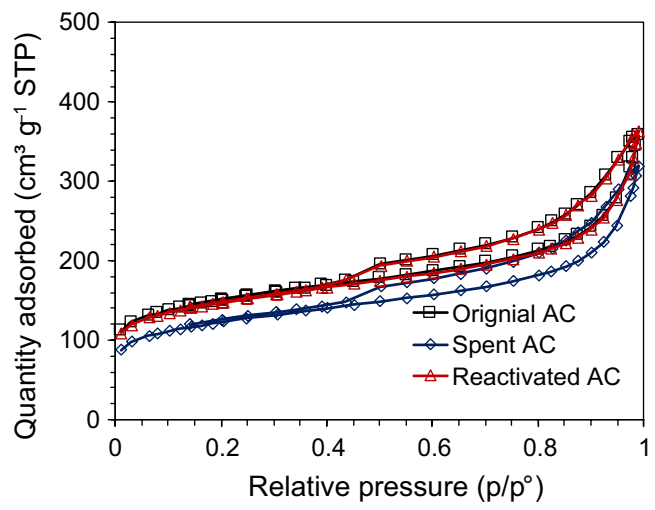

b

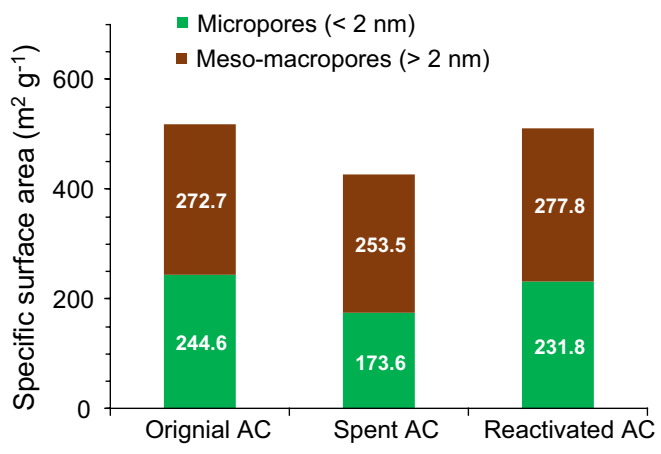

Fig. 4 Isothermal plots (a) and surface areas of the original, spent and reactivated AC (b) 
overliming and reactivated $\mathrm{AC}$ was similar to that in sequential overliming and original $\mathrm{AC}(8.4 \%$ vs $8.0 \%)$. Approximately $94.2 \%$ of total sugars were consumed in $48 \mathrm{~h}$ and the final butanol concentration reached $13.81 \mathrm{~g} \mathrm{~L}^{-1}$. The butanol and ABE yield reached 0.22 and $0.34 \mathrm{~g} \mathrm{~g}^{-1}$ sugar, respectively (Fig. $5 \mathrm{a}$ ). The results indicated that $\mathrm{AC}$ can be recycled in the sequential detoxification of biomass prehydrolysate for $\mathrm{ABE}$ fermentation (Fig. 5b).

\section{Conclusions}

Overliming and $\mathrm{AC}$ alone could not make the prehydrolysates fermentable with $C$. saccharobutylicum. The sequential overliming and $\mathrm{AC}$ resulted in remarkable fermentability and high butanol yield at $0.22 \mathrm{~g} \mathrm{~g}^{-1}$ sugar, which was close to the pure glucose fermentation $\left(0.25 \mathrm{~g} \mathrm{~g} \mathrm{~g}^{-1}\right.$ sugar). The synergistic effect of overliming and $\mathrm{AC}$ detoxification on $\mathrm{ABE}$ fermentation was perceived. It was observed that aliphatic acids were not changed with overliming and $\mathrm{AC}$ treatment. However, the overliming and $\mathrm{AC}$ showed significant difference in phenolic acid removal. Overliming removed much more 2,5-furandicarboxyaldehyde, 5-ethylfuran-2-carbaldehyde and 2,5-hexanedione compared to AC treatment, while AC treatment removed more phenolic acids than overliming. The difference in removing the dialdehydes/ diketones and phenolic acids by overliming and AC could be the main reason for their synergic effect in detoxification of the prehydrolysates for ABE fermentation.

It was observed that $\mathrm{AC}$ was more effective in removing phenolic acids due to their hydrophobicity and overliming was more selective in removing certain dialdehydes and diketones due to the base-catalyzed aldocondensation reactions. The effect of AC detoxification depended on the amount of $\mathrm{AC}$ used in the process. Yeast showed much more tolerance to the overliming treated prehydrolysate than C. acetobutylicum. The study suggested a different detoxification was needed for $\mathrm{ABE}$ fermentation of the biomass prehydrolysate as compared to ethanol fermentation.

\section{Methods}

\section{Chemicals and microorganisms}

Glucose, Reinforced Clostridial Medium (RCM), $\mathrm{MgSO}_{4}$, $\mathrm{K}_{2} \mathrm{HPO}_{4}, \quad \mathrm{KH}_{2} \mathrm{PO}_{4}, \quad \mathrm{MnSO}_{4} \cdot \mathrm{H}_{2} \mathrm{O}, \quad \mathrm{FeSO}_{4} \cdot 7 \mathrm{H}_{2} \mathrm{O}$ and agar were obtained from VWR (Radnor, PA). Granular activated carbon (20-40 mesh), $\mathrm{Ca}(\mathrm{OH})_{2}$, and $\mathrm{CH}_{3} \mathrm{COONH}_{4}$, were purchased from Alfa Aesar (Ward Hill, MA). $\mathrm{NaCl}$ and $\mathrm{CaCO}_{3}$ were obtained from Fisher Scientific (Fair Lawn, NJ). Biotin, $\mathrm{H}_{2} \mathrm{SO}_{4}$ (96\%), $\mathrm{HCl}$, $p$-aminobenzoic acid, thiamine, and yeast extract were acquired from Sigma Aldrich (St. Louis, MO). Peptone was purchased from Research Products International (Prospect, IL). Stock solutions (i.e., buffer, mineral, and vitamin) were prepared and stored at $4{ }^{\circ} \mathrm{C}$. Buffer solution contained $\mathrm{K}_{2} \mathrm{HPO}_{4}, \mathrm{KH}_{2} \mathrm{PO}_{4}$, and $\mathrm{CH}_{3} \mathrm{COONH}_{4}$ at the concentration of 50,50 , and $220 \mathrm{~g} \mathrm{~L}^{-1}$, respectively. The mineral solution contained $40,2,2$, and $2 \mathrm{~g} \mathrm{~L}^{-1}$ of $\mathrm{MgSO}_{4} \cdot 7 \mathrm{H}_{2} \mathrm{O}, \mathrm{MnSO}_{4} \cdot \mathrm{H}_{2} \mathrm{O}, \mathrm{FeSO}_{4} \cdot 7 \mathrm{H}_{2} \mathrm{O}$, and $\mathrm{NaCl}$, respectively. Vitamin solution was composed of 1,1 , and $0.01 \mathrm{~g} \mathrm{~L}^{-1}$ of $p$-aminobenzoic acid, thiamine, and biotin, respectively.

The strain for ABE fermentation (Clostridium saccharobutylicum BAA-117) was acquired from the American Type Culture Collection. The spore suspensions were stored in sterilized deionized (DI) water at $4{ }^{\circ} \mathrm{C}$. RCM medium $\left(38 \mathrm{~g} \mathrm{~L}^{-1}\right)$ was autoclaved $\left(121^{\circ} \mathrm{C}\right)$ for $15 \mathrm{~min}$ and then sparged with nitrogen to remove the oxygen. The spores were heat-shock $\left(75^{\circ} \mathrm{C}\right)$ for $10 \mathrm{~min}$, inoculated to the sterilized RCM medium $(50 \mathrm{~mL})$, and then incubated $\left(35{ }^{\circ} \mathrm{C}\right)$ in anaerobic chamber for $16-18 \mathrm{~h}$. The optical density $\left(\mathrm{OD}_{600}\right)$ was tested by UV-Vis
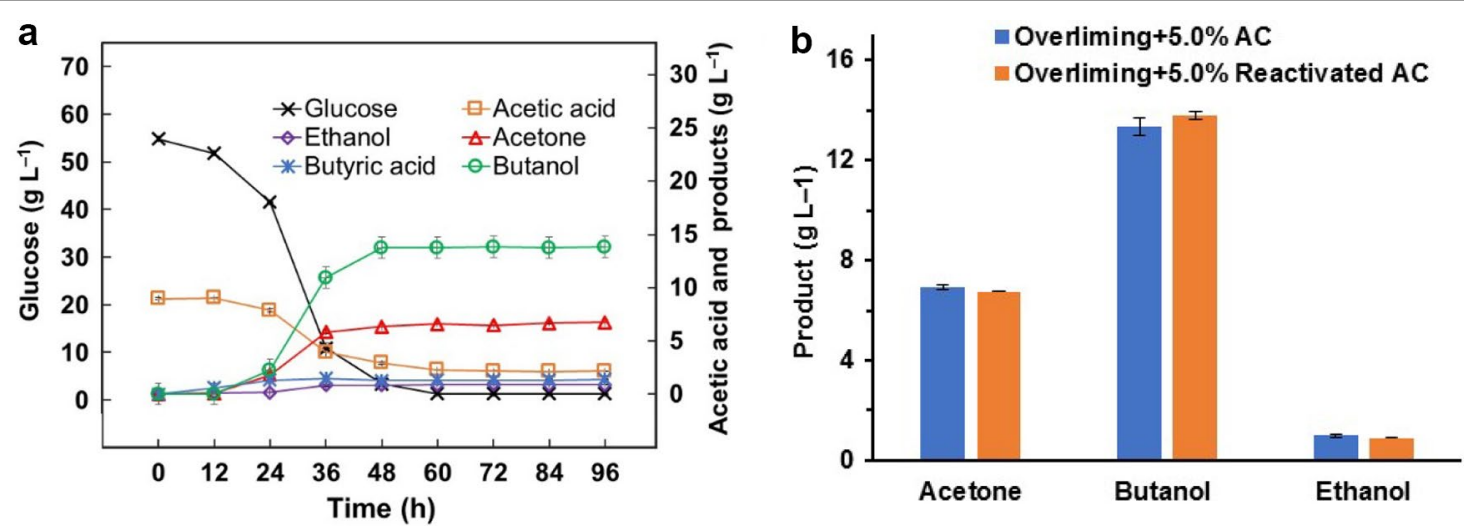

Fig. 5 ABE fermentation of the prehydrolysate detoxified by sequential overliming and reactivated $A C$. a glucose consumption and $A B E$ production, $\mathbf{b}$ ABE production comparison between original $A C$ and reactivated AC detoxification 
spectrophotometer in terms of the absorption intensity at $600 \mathrm{~nm}$ to determine the cell concentration [39]. The cell was inoculated for fermentation with an $\mathrm{OD}_{600}$ value of 1.30 .

The baker's yeast S. cerevisiae (Fleischmann's) was used for the ethanol fermentation. The yeast extract peptone dextrose medium (YPD), including glucose $\left(20 \mathrm{~g} \mathrm{~L}^{-1}\right)$, peptone $\left(20 \mathrm{~g} \mathrm{~L}^{-1}\right)$, yeast extract $\left(10 \mathrm{~g} \mathrm{~L}^{-1}\right)$, were prepared and sterilized. The yeast was pre-activated in YPD medium overnight, followed by washing with sterilized $\mathrm{DI}$ water. The $\mathrm{OD}_{600}$ were tested to determine the yeast concentration [30]. The initial inoculum concentration was $1.0 \mathrm{~g} \mathrm{~L}^{-1}$ for the yeast fermentation.

\section{Dilute acid pretreatment of biomass}

Hybrid poplar (Populus) (0.25-in. grind) was provided by Idaho National Laboratory (Oregon, USA). The chemical composition of the untreated poplar was $49.42 \%$ glucan, $14.63 \%$ xylan, $0.80 \%$ galactan, $0.19 \%$ arabinan, $1.14 \%$ mannan, $26.69 \%$ lignin, $0.24 \%$ ash and $2.04 \%$ extractives. Before the hydrothermal reaction, $200 \mathrm{~g}$ of wood chips (dry weight) were soaked in $1.4 \mathrm{~L}$ aqueous $1.0 \%(w / v)$ sulfuric acid solution overnight. The pretreatment was conducted in a 2-L Parr batch reactor at $160{ }^{\circ} \mathrm{C}$ for $1 \mathrm{~h}$. After cooling down to room temperature, the liquid fraction (prehydrolysate) from dilute sulfuric acid pretreatment was separated by vacuum filtration and stored at $4{ }^{\circ} \mathrm{C}$.

\section{Detoxification of biomass prehydrolysates with $\mathrm{Ca}(\mathrm{OH})_{2}$ and activated carbon}

$\mathrm{Ca}(\mathrm{OH})_{2}$ was added to adjust the $\mathrm{pH}$ of the prehydrolysates to 6 . The glucose concentrations in the prehydrolysates were brought to approximately $65.75 \mathrm{~g} \mathrm{~L}^{-1}$ by adding around $55 \mathrm{~g} \mathrm{~L}^{-1}$ pure glucose. For the yeast fermentation, $10 \mathrm{~g} \mathrm{~L}^{-1}$ additional glucose was supplemented to make a final concentration of $20.75 \mathrm{~g} \mathrm{~L}^{-1}$. Overliming and $\mathrm{AC}$ treatments were performed to detoxify the prehydrolysates. All the detoxification treatments were conducted in duplicates.

Overliming method was used to detoxify the prehydrolysate [30]. Briefly, the $\mathrm{pH}$ value of the prehydrolysate $(1 \mathrm{~L})$ was brought to 10 with $15.32 \mathrm{~g}$ of $\mathrm{Ca}(\mathrm{OH})_{2}$. The prehydrolysate was then heated in a $60^{\circ} \mathrm{C}$ water bath for $2 \mathrm{~h}$. Subsequently, the $\mathrm{pH}$ of the prehydrolysate was adjusted to the desirable fermentation condition $(\mathrm{pH}=6)$ using $\mathrm{H}_{2} \mathrm{SO}_{4}$. After removing the precipitates by centrifugation, the liquid phase was kept for GC/MS analysis and fermentation. The volume change after overliming treatment was negligible.

The AC treatment of the prehydrolysate $(\mathrm{pH}=6)$ was conducted in a $250-\mathrm{mL}$ shake flask with ground-glass stopper. After mixing $100 \mathrm{~mL}$ of prehydrolysate and 5.0\% $(w / v)$ of $\mathrm{AC}$, the flask was placed on an orbital shaker
(200 rpm) for $2 \mathrm{~h}$. The prehydrolysate was collected after removing $\mathrm{AC}$ by vacuum filtration. DI water was supplemented to bring the prehydrolysate to the original volume.

The sequential overliming and AC method was performed for the detoxification of the prehydrolysate. Firstly, the prehydrolysate was detoxified by overliming method described previously. After removing the precipitates, the AC detoxification was performed in the overliming treated prehydrolysate. The adding amounts of AC were 1.0, 2.5, 5.0 and $10.0 \%(w / v)$, respectively, for the sequential overliming and $\mathrm{AC}$ detoxification.

\section{$\mathrm{ABE}$ and yeast fermentation}

For each fermentation broth, the solution was adjusted to $\mathrm{pH}=6$ and filtered through the membrane syringe filter $(0.22 \mu \mathrm{m})$ for sterilization. ABE fermentation was performed in a $125-\mathrm{mL}$ serum bottle. The fermentation medium was composed of $45 \mathrm{~mL}$ of corresponding prehydrolysate (glucose concentration: $60 \mathrm{~g} \mathrm{~L}^{-1}$ ), yeast extract $\left(1 \mathrm{~g} \mathrm{~L}^{-1}\right), 0.5 \mathrm{~mL}$ buffer, $0.25 \mathrm{~mL}$ mineral, and $50 \mu \mathrm{L}$ vitamin solutions. $\mathrm{CaCO}_{3}$ powder $(0.25 \mathrm{~g})$ was added to maintain the $\mathrm{pH}$ during the fermentation process. After sparging with nitrogen for $10 \mathrm{~min}$ to purge the oxygen, the medium was immediately transferred into an anaerobic chamber. A $10 \%(v / v)$ growing bacteria was inoculated into the serum bottle to achieve a final volume of $50 \mathrm{~mL}$. A rubber stopper and an aluminum sealing cap were used to seal the serum bottle. A needle $(0.8 \mathrm{~mm} \times 40 \mathrm{~mm})$ was inserted into the rubber stopper to release the internal pressure. The bottle was incubated at $35^{\circ} \mathrm{C}$ and samples $(0.5 \mathrm{~mL})$ were taken every $12 \mathrm{~h}$ until $96 \mathrm{~h}$ for HPLC analyses. The fermentation was conducted in duplicates.

Yeast fermentation was conducted in a 250-mL flask with $50 \mathrm{~mL}$ of the untreated or overliming-treated prehydrolysate. The glucose blank $\left(20 \mathrm{~g} \mathrm{~L}^{-1}\right)$ was prepared as reference fermentation. After inoculation of yeast, the flask was placed in an incubator shaker $(150 \mathrm{rpm})$ at $30{ }^{\circ} \mathrm{C}$. The samples $(0.5 \mathrm{~mL})$ were collected for HPLC analyses at $0,1,3,6,9,12,24$ and $48 \mathrm{~h}$, respectively.

\section{High-performance liquid chromatography (HPLC) analysis}

Quantification of the fermentation products and short chain aliphatic acids were achieved with by an Agilent 2600 HPLC system (Detector: RID-10A; Column: Agilent Hi-Plex $\mathrm{H}$ ). The mobile phase (aqueous $5 \mathrm{mM}$ sulfuric acid solution) flow rate was at $0.6 \mathrm{~mL} \mathrm{~min}^{-1}$. The column temperature was kept at $45{ }^{\circ} \mathrm{C}$ throughout the sample run. The biomass sugars were quantified with a Bio-Rad HPX-87P column by the same HPLC system. The column temperature was maintained at $80{ }^{\circ} \mathrm{C}$ with DI water at the same flow rate for $35 \mathrm{~min}$. According to the HPLC 
analysis, the prehydrolysates contained glucose $(10.85 \mathrm{~g}$ $\left.\mathrm{L}^{-1}\right)$, xylose $\left(8.93 \mathrm{~g} \mathrm{~L}^{-1}\right)$, galactose $\left(1.04 \mathrm{~g} \mathrm{~L}^{-1}\right)$, arabinose $\left(0.64 \mathrm{~g} \mathrm{~L}^{-1}\right)$, mannose $\left(1.94 \mathrm{~g} \mathrm{~L}^{-1}\right)$, and sugar degradation compounds including formic acid $\left(1.15 \mathrm{~g} \mathrm{~L}^{-1}\right)$, acetic acid (6.08 $\left.\mathrm{g} \mathrm{L}^{-1}\right)$, levulinic acid $\left(1.12 \mathrm{~g} \mathrm{~L}^{-1}\right)$, HMF $\left(0.63 \mathrm{~g} \mathrm{~L}^{-1}\right)$ and furfural $\left(4.94 \mathrm{~g} \mathrm{~L}^{-1}\right)$. The furfural concentration was higher than the result from GC/MS because of the loss from solvent extraction and nitrogen blowing. An Agilent 1290 LC-6540 connected to a quadrupole time-of-flight (Q-TOF) mass spectrometer was used to determine the phenolic acid removal. An Agilent Zorbax Eclipse Plus C18 column $(4.6 \times 100 \mathrm{~mm}, 3.5 \mu \mathrm{m}$ particle size $)$ was used to separate the phenolic acids in the prehydrolysate. The flow rate was controlled at $0.5 \mathrm{~mL} \mathrm{~min}{ }^{-1}$ with two eluents: (A) $\mathrm{H}_{2} \mathrm{O}$ with $5 \mathrm{mM}$ ammonium acetate and (B) acetonitrile with $5 \mathrm{mM}$ ammonium acetate. The gradient started from 95\% A during the first minute, then decreased to 5\% A at $8 \mathrm{~min}$ and held for $1 \mathrm{~min}$, and finally changed back to $95 \% \mathrm{~A}$. The electrospray ionization (ESI) parameter was maintained as gas temperature $\left(350{ }^{\circ} \mathrm{C}\right)$, gas flow $\left(8 \mathrm{~L} \mathrm{~min}^{-1}\right)$ and capillary voltage $(3.5 \mathrm{kV})$ at negative mode. The analysis scan was from 50 to $500 \mathrm{~m} / z$.

\section{Gas chromatography-mass spectrometry (GC/MS) analysis}

To isolate the carbonyl inhibitors from the prehydrolysate, same amount of DCM $(50 \mathrm{~mL})$ was used to extract the compounds from $50 \mathrm{~mL}$ prehydrolysate twice. After going through anhydrous sodium sulfate $(\sim 10 \mathrm{~g})$ column, the DCM-extracted solution was collected, and then concentrated to $5 \mathrm{~mL}$ by a nitrogen blowing concentrator (TurboVap II workstation). GC/MS analysis was performed on an Agilent 7890A GC and 7000 mass selective detector triple quadrupole. A DB-5 capillary column (J \& W Scientific, $30 \mathrm{~m}$ length, $0.25 \mathrm{~mm}$ i.d., and $0.25 \mu \mathrm{m}$ thickness) was employed to achieve chromatographic separation of the analytes. The electron ionization ion source was maintained at $250{ }^{\circ} \mathrm{C}$ and $70 \mathrm{eV}$. The mass spectra were scanned from 30 to 700 . The oven temperature was held at $60^{\circ} \mathrm{C}$ for 4 min to delay the solvents, and then increased to $105{ }^{\circ} \mathrm{C}\left(12{ }^{\circ} \mathrm{C} \mathrm{min}-1\right.$ ramping, $2 \mathrm{~min}$ holding); to $160{ }^{\circ} \mathrm{C}\left(15^{\circ} \mathrm{C} \mathrm{min}^{-1}\right.$ ramping, 1 min holding); to $250^{\circ} \mathrm{C}\left(10^{\circ} \mathrm{C} \mathrm{min}^{-1}\right.$ ramping, 2 min holding $)$; and finally increased to $315{ }^{\circ} \mathrm{C}\left(10{ }^{\circ} \mathrm{C} \mathrm{min}^{-1}\right.$ ramping, $8 \mathrm{~min}$ holding). The accumulated running time was $40 \mathrm{~min}$.

\section{Surface area analysis of activated carbon}

The surface area of AC was determined by an ASAP 2020 surface area and porosity analyzer, using nitrogen absorption method. The ACs were vacuum degassed $\left(250{ }^{\circ} \mathrm{C}\right)$ for $20 \mathrm{~h}$ before the analysis. Based on the isothermal plots obtained from the analysis, the BET total surface areas and $\mathrm{t}$-plot micropore $[<2 \mathrm{~nm}$, defined by IUPAC (International Union of Pure and Applied Chemists)] surface areas of the samples were obtained. The surface area of meso- and macropore ( $\geq 2 \mathrm{~nm}$ ) was calculated by subtracting the corresponding micropore surface area from the BET total surface area.

\section{Reactivation process of activated carbon}

The spent $\mathrm{AC}$ collected from detoxification process was washed by $1 \mathrm{M} \mathrm{HCl}$ aqueous solution. After being dried at $105{ }^{\circ} \mathrm{C}$ for approximate $20 \mathrm{~h}$, the sample was transferred to a tube furnace, and reactivated at $650^{\circ} \mathrm{C}$ for $2 \mathrm{~h}$ with the flow of nitrogen gas $\left(10 \mathrm{~cm}^{3} \mathrm{~min}^{-1}\right)$ [53]. After cooling down to room temperature, the surface area of the reactivated $\mathrm{AC}$ was determined. The efficiency of the detoxification using the reactivated $\mathrm{AC}$ was evaluated.

\section{Additional file}

Additional file 1: Figures S1-S46. MS spectra of the tentatively identified compounds. Figure S47. Structures of the tentatively identified carbonyl inhibitors from the poplar prehydrolysate by GC/MS. Figure S48. UV-Vis spectra of the untreated poplar prehydrolysate, the prehydrolysates after overliming, 5.0\% AC and sequential overliming with 1.0, 2.5, 5.0 and $10.0 \%$ AC. Figure S49. TIC-GC/MS chromatogram of the prehydrolysate detoxified with sequential overliming and $2.5 \%$ AC.

\section{Abbreviations}

GC/MS: gas chromatography-mass spectrometry; AC: activated carbon; ABE: acetone-butanol-ethanol; HMF: hydroxymethylfurfural; DCM: dichloromethane; UV-Vis: ultraviolet-visible; BET: Brunauer-Emmett-Teller; OD: optical density; YPD: peptone dextrose medium; HPLC: high-performance liquid chromatography; Q-TOF: quadrupole time-of-flight; ESI: electrospray ionization.

\section{Authors' contributions}

YZ conducted the major experiments and data analysis. CX assisted the GC/ MS method develop, data collection and analysis. MT conceived and designed the project and supervised the experiments. YZ, CX, ML and MT wrote the manuscript. All authors read and approved the final manuscript.

\section{Acknowledgements}

We owe our appreciation to Dr. Zhiqiang (Mark) Wang (Environmental Analysis Service Center, University of Cincinnati) for assisting the GC/MS analysis.

\section{Competing interests}

The authors declare that they have no competing interests.

\section{Availability of data and materials}

All data generated or analyzed during this study are included in this published article and its additional files.

Consent for publication

All authors consented on the publication of this work.

Ethics approval and consent to participate Not applicable.

\section{Funding}

This research was funded by National Science Foundation (NSF-CBET 1555633).

\section{Publisher's Note}

Springer Nature remains neutral with regard to jurisdictional claims in published maps and institutional affiliations. 
Received: 5 April 2018 Accepted: 20 June 2018

Published online: 26 June 2018

\section{References}

1. Lynd LR. The grand challenge of cellulosic biofuels. Nat Biotechnol. 2017;35:912-5.

2. Yang B, Wyman CE. Pretreatment: the key to unlocking low-cost cellulosic ethanol. Biofuels Bioprod Biorefin. 2008;2:26-40.

3. Mussatto SI, Roberto IC. Alternatives for detoxification of diluted-acid lignocellulosic hydrolyzates for use in fermentative processes: a review. Bioresour Technol. 2004:93:1-10.

4. Martinez A, Rodriguez ME, York SW, Preston JF, Ingram LO. Effects of $\mathrm{Ca}(\mathrm{OH})(2)$ treatments ("overliming") on the composition and toxicity of bagasse hemicellulose hydrolysates. Biotechnol Bioeng. 2000;69:526-36.

5. Alriksson B, Horvath IS, Sjode A, Nilvebrant NO, Jonsson LJ. Ammonium hydroxide detoxification of spruce acid hydrolysates. Appl Biochem Biotechnol. 2005;121:911-22.

6. Palmqvist $\mathrm{E}$, Hahn-Hägerdal B. Fermentation of lignocellulosic hydrolysates. II: inhibitors and mechanisms of inhibition. Bioresour Technol. 2000;74:25-33.

7. Jönsson $\sqcup$, Alriksson B, Nilvebrant N-O. Bioconversion of lignocellulose: inhibitors and detoxification. Biotechnol Biofuels. 2013;6:16.

8. Klinke HB, Thomsen A, Ahring BK. Inhibition of ethanol-producing yeast and bacteria by degradation products produced during pre-treatment of biomass. Appl Microbiol Biotechnol. 2004;66:10-26.

9. Chandel AK, Da Silva SS, Singh OV. Detoxification of lignocellulose hydrolysates: biochemical and metabolic engineering toward white biotechnology. BioEnergy Res. 2013;6:388-401.

10. Klinke HB, Thomsen AB, Ahring BK. Inhibition of ethanol-producing yeast and bacteria by degradation products produced during pre-treatment of biomass. Appl Microbiol Biot. 2004;66:10-26.

11. Olsson L, HahnHagerdal B. Fermentation of lignocellulosic hydrolysates for ethanol production. Enzyme Microb Technol. 1996:18:312-31.

12. Sharma LN, Becker C, Chambliss CK. Analytical characterization of fermentation inhibitors in biomass pretreatment samples using liquid chromatography, UV-visible spectroscopy, and tandem mass spectrom etry. Biofuels: Methods and Protocols. Totowa: Humana Press; 2009. p. $125-43$.

13. Klinke HB, Ahring BK, Schmidt AS, Thomsen AB. Characterization of degradation products from alkaline wet oxidation of wheat straw. Bioresour Technol. 2002;82:15-26.

14. Chen SF, Mowery RA, Castleberry VA, van Walsum GP, Chambliss CK. Highperformance liquid chromatography method for simultaneous determination of aliphatic acid, aromatic acid and neutral degradation products in biomass pretreatment hydrolysates. J Chromatogr A. 2006;1104:54-61.

15. Xie R, Tu M, Carvin J, Wu Y. Detoxification of biomass hydrolysates with nucleophilic amino acids enhances alcoholic fermentation. Bioresour Technol. 2015;186:106-13.

16. Wang SZ, Cheng G, Joshua C, He ZJ, Sun XX, Li RM, Liu LX, Yuan QP. Furfural tolerance and detoxification mechanism in Candida tropicalis. Biotechnol Biofuels. 2016:9:250.

17. Zaldivar J, Martinez A, Ingram LO. Effect of alcohol compounds found in hemicellulose hydrolysate on the growth and fermentation of ethanologenic Escherichia coli. Biotechnol Bioeng. 2000;68:524-30.

18. Zaldivar J, Martinez A, Ingram LO. Effect of selected aldehydes on the growth and fermentation of ethanologenic Escherichia coli. Biotechnol Bioeng. 1999:65:24-33.

19. Wang S, Sun X, Yuan Q. Strategies for enhancing microbial tolerance to inhibitors for biofuel production: a review. Bioresour Technol. 2018:258:302-9.

20. Ando S, Arai I, Kiyoto K, Hanai S. Identification of aromatic monomers in steam-exploded poplar and their influences on ethanol fermentation by Saccharomyces cerevisiae. J Fermen Technol. 1986;64:567-70.

21. Horvath IS, Sjode A, Alriksson B, Jonsson LJ, Nilvebrant NO. Critical conditions for improved fermentability during overliming of acid hydrolysates from spruce. Appl Biochem Biotechnol. 2005;121:1031-44.

22. Maddox IS, Murray AE. Production of n-butanol by fermentation of wood hydrolysate. Biotechnol Lett. 1983;5:175-8.
23. Lee JM, Venditti RA, Jameel H, Kenealy WR. Detoxification of woody hydrolyzates with activated carbon for bioconversion to ethanol by the thermophilic anaerobic bacterium Thermoanaerobacterium saccharolyticum. Biomass Bioenerg. 2011;35:626-36.

24. Kim Y, Ximenes E, Mosier NS, Ladisch MR. Soluble inhibitors/deactivators of cellulase enzymes from lignocellulosic biomass. Enzyme Microb Technol. 2011:48:408-15.

25. Larsson S, Reimann A, Nilvebrant NO, Jonsson LJ. Comparison of different methods for the detoxification of lignocellulose hydrolyzates of spruce. Appl Biochem Biotechnol. 1999;77-9:91-103.

26. Martinez A, Rodriguez ME, Wells ML, York SW, Preston JF, Ingram LO. Detoxification of dilute acid hydrolysates of lignocellulose with lime. Biotechnol Progr. 2001;17:287-93.

27. Millati R, Niklasson C, Taherzadeh MJ. Effect of $\mathrm{pH}$, time and temperature of overliming on detoxification of dilute-acid hydrolyzates for fermentation by Saccharomyces cerevisiae. Process Biochem. 2002;38:515-22.

28. Andary J, Maalouly J, Ouaini R, Chebib H, Beyrouthy M, Rutledge DN, Ouaini N. Phenolic compounds from diluted acid hydrolysates of olive stones: effect of overliming. Adv Crop Sci Technol. 2013;1:103.

29. Palmqvist $E$, Hahn-Hägerdal B. Fermentation of lignocellulosic hydrolysates. I: inhibition and detoxification. Bioresour Technol. 2000;74:17-24.

30. Xie R, Tu M, Wu Y, Taylor S. Reducing sugars facilitated carbonyl condensation in detoxification of carbonyl aldehyde model compounds for bioethanol fermentation. RSC Adv. 2012:2:7699-707.

31. Martín C, Galbe M, Wahlbom CF, HahnHägerdal B, Jönsson L. Ethano production from enzymatic hydrolysates of sugarcane bagasse using recombinant xylose-utilising Saccharomyces cerevisiae. Enzyme Microb Technol. 2002;31:274-82.

32. Lu C, Dong J, Yang S-T. Butanol production from wood pulping hydrolysate in an integrated fermentation-gas stripping process. Bioresour Technol. 2013;143:467-75.

33. Mussatto SI, Santos JC, Roberto IC. Effect of pH and activated charcoal adsorption on hemicellulosic hydrolysate detoxification for xylitol production. J Chem Technol Biot. 2004;79:590-6.

34. Gong C, Chen C, Chen L. Pretreatment of sugar cane bagasse hemicellulose hydrolyzate for ethanol production by yeast. Appl Biochem Biotechnol. 1993;39:83-8.

35. Wang L, Fan X, Tang P, Yuan Q. Xylitol fermentation using hemicellulose hydrolysate prepared by acid pre-impregnated steam explosion of corncob. J Chem Technol Biotechnol. 2013;88:2067-74.

36. Villarreal M, Prata A, Felipe M, Silva JAE. Detoxification procedures of eucalyptus hemicellulose hydrolysate for xylitol production by Candida guilliermondii. Enzyme Microb Technol. 2006;40:17-24.

37. Ezeji T, Qureshi N, Blaschek HP. Butanol production from agricultural residues: impact of degradation products on Clostridium beijerinckii growth and butanol fermentation. Biotechnol Bioeng. 2007;97:1460-9.

38. Miller EN, Jarboe LR, Turner PC, Pharkya P, Yomano LP, York SW, Nunn D, Shanmugam KT, Ingram LO. Furfural inhibits growth by limiting sulfur assimilation in ethanologenic Escherichia coli strain LY180. Appl Environ Microb. 2009;75:6132-41

39. Li J, Shi S, Adhikari S, Tu M. Inhibition effect of aromatic aldehydes on butanol fermentation by Clostridium acetobutylicum. RSC Adv. 2017:7:1241-50.

40. Chandel AK, Kapoor RK, Singh A, Kuhad RC. Detoxification of sugarcane bagasse hydrolysate improves ethanol production by Candida shehatae NCIM 3501. Bioresour Technol. 2007;98:1947-50.

41. Lee SC, Park S. Removal of furan and phenolic compounds from simulated biomass hydrolysates by batch adsorption and continuous fixedbed column adsorption methods. Bioresour Technol. 2016;216:661-8.

42. Martinez A, Rodriguez ME, York SW, Preston JF, Ingram LO. Use of UV absorbance to monitor furans in dilute acid hydrolysates of biomass. Biotechnol Progr. 2000;16:637-41.

43. Luo CD, Brink DL, Blanch HW. Identification of potential fermentation inhibitors in conversion of hybrid poplar hydrolyzate to ethanol. Biomass Bioenerg. 2002;22:125-38

44. Xue C, Zhang XT, Wang JF, Xiao M, Chen LJ, Bai FW. The advanced strategy for enhancing biobutanol production and high-efficient product recovery with reduced wastewater generation. Biotechnol Biofuels. 2017;10:148.

45. Cho DH, Lee YJ, Um Y, Sang Bl, Kim YH. Detoxification of model phenolic compounds in lignocellulosic hydrolysates with peroxidase for 
butanol production from Clostridium beijerinckii. Appl Microbiol Biot. 2009:83:1035-43.

46. Kamal SMM, Mohamad NL, Abdullah AGL, Abdullah N. Detoxification of sago trunk hydrolysate using activated charcoal for xylitol production. Procedia Food Sci. 2011;1:908-13.

47. Converti A, Perego P, Domínguez JM. Xylitol production from hardwood hemicellulose hydrolysates by Pachysolen tannophilus, Debaryomyces hansenii, and Candida guilliermondii. Appl Biochem Biotechnol. 1999;82:141-51.

48. Liu Z, Slininger P, Dien B, Berhow M, Kurtzman C, Gorsich S. Adaptive response of yeasts to furfural and 5 -hydroxymethylfurfural and new chemical evidence for HMF conversion to 2,5-bis-hydroxymethylfuran. J Ind Microbiol Biotechnol. 2004;31:345-52.

49. Liu ZL, Blaschek HP. Biomass conversion inhibitors and in situ detoxification. Biomass Biofuels. 2010. https://doi.org/10.1002/9780470750025. ch12.
50. Liu ZL. Molecular mechanisms of yeast tolerance and in situ detoxification of lignocellulose hydrolysates. Appl Microbiol Biotechnol. 2011;90:809-25.

51. Delgenes J, Moletta R, Navarro J. Effects of lignocellulose degradation products on ethanol fermentations of glucose and xylose by Saccharomyces cerevisiae, Zymomonas mobilis, Pichia stipitis, and Candida shehatae. Enzyme Microb Technol. 1996;19:220-5.

52. Ranatunga T, Jervis J, Helm R, McMillan J, Hatzis C. Toxicity of hardwood extractives toward Saccharomyces cerevisiae glucose fermentation. Biotechnol Lett. 1997;19:1125-7.

53. Sabio E, González E, González J, González-Garcia C, Ramiro A, Ganan J. Thermal regeneration of activated carbon saturated with $\mathrm{p}$-nitrophenol. Carbon. 2004;42:2285-93.
Ready to submit your research? Choose BMC and benefit from:

- fast, convenient online submission

- thorough peer review by experienced researchers in your field

- rapid publication on acceptance

- support for research data, including large and complex data types

- gold Open Access which fosters wider collaboration and increased citations

- maximum visibility for your research: over 100M website views per year

At BMC, research is always in progress.

Learn more biomedcentral.com/submissions 